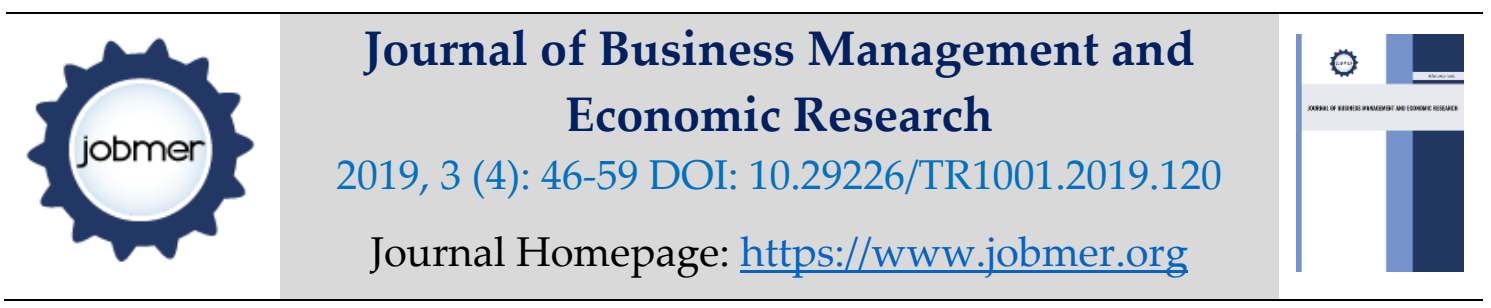

\title{
The Future of International Road Freight Transport Companies in Turkey: Challenges and Solutions
}

\author{
Cemalettin AKTEPE (Ph. D.) \\ Ankara Hacı Bayram Veli University / Turkey \\ Faculty of Economics and Administrative Sciences, Department of International Trade \\ c.aktepe@hbv.edu.tr
}

\begin{abstract}
Road freight transport is not considered to be one of the largest transportation modes of our time, though it has continued to be one of the most important considerations of international trade throughout the history. Today, although the majority of international trade is known to be carried by sea transport, road freight transport is still of particular importance for our country. A relatively significant portion of our exports and imports has been carried out by road freight transport. Considering the last five years, $35 \%$ of our exports and $16 \%$ of our imports are realized through road freight transport. Despite these rates, road freight transport is expected to have a shrinking share due to the efforts to reduce its share over time because of both the high costs and harms it causes to the environment. On the other hand, considering the number of transportation vehicles, Turkey ranks 11th in the world, which signals that the country needs to produce new policies for road freight transport of goods. The aim of this study is to present the current situation of the companies in Turkey that carry out international road freight transport and the measures they take and are required to take and to suggest a prospective vision. For this purpose, the researcher carries out a situation analysis via face-to-face interviews with six logistics companies carrying international goods and develops alternatives solutions to the existing problems.
\end{abstract}

Keywords: International trade, logistics, road freight transport of goods

\section{Introduction}

There are many suboperations in international trade logistics. In addition to storage, packaging, labeling, customs clearance of goods, and insurance, one of the most important issues undoubtedly is international transportation. Each of these processes closely affects the performance of the other. An error or a deficiency that may occur can easily affect the entire transportation system. 
In addition to sea, rail, and air transport, road freight transport also creates a significant financial growth in many regions.

Increasing competition and crises as a result of globalization necessitate the reduction of profit margins and transportation in optimal time (Küçük, 2014,65). On the other hand service purchases, such as transportation, contain a considerable amount of detail according to the purchase of goods. Therefore, the margin of error increases (Cora, 2016, 9).

The road freight transport, which is quite ideal for the delivery of goods that are not transported too far and excessively high in tonnage and appears to be one of the frequently-used modes of transports in international trade, is the primary mode of transportation for the export and import operations in Turkey (Dölek, 2015, p.16).

While cheaper, safer, and faster modes of transportation have been developing and influencing the preferences of the industry, the road freight transport continues to be significant in Turkey as in many parts of the world. As of today, approximately $50 \%$ of our exports are carried out by road.

Nowadays, road freight transport is the most preferred mode of transportation since it is reliable. It is widely used and can make more cargo transported. All modes of transportation, e.g. moving a house or a factory, are realized via road freight transport. Road freight transport is the most commonly used modes of transportation for both the convenience and costs (www.webnak.com.tr). It is considered to be effective particularly in countries/regions where there are border trade and regional integration. In China, one of the most important agents in world trade, a significant correlation is observed between the quantity of the road freight transport of goods and the regional agreements. This development can be accounted not only for China but also for the European Union, which is considered to be the most important regional integration of the world.

The existence of practices that ensure the compatibility of the road freight transport with the other modes of transportation helps maintain the share of road freight transport. For example, while Ro-Ro transport makes the sea transport possible, road freight transport linked with rail transport systems is also increasing due to the increase in international integration.

Considering the particular case of Turkey, the fact that the destinations within a 40-hour transport period make up a significant portion $(60 \%)$ of our exports can be a strong proof that road freight transport is indispensable. Therefore, it is important to demonstrate the pros and cons of road 
freight transport with a good analysis and identify common policies. Accordingly, the following factors can be listed in order to sort out the pros of road freight transport.

- The most important advantage of road freight transport is that it allows the transportation of low amount of products in short and medium distances in a flexible and fast manner. Thus, it enables the companies that handle order-based work to make 'Just in Time' deliveries.

- Besides, the expected waiting time in the ports is bypassed thanks to the road freight transports, and the goods can directly be delivered to the customers' warehouses. The goods can be delivered to the buyers by road freight transport as safely as sea transports.

- There is usually very little need for terminals.

- It is the most convenient way to connect the whole production and consumption centers, that is, door-to-door transport.

- The transportation network is almost with no borders under appropriate geographical conditions.

- It provides fast service.

- It allows 24/7 loading/unloading/departing and provides convenience in loading and unloading.

- It makes searching and managing rental vehicles easy and allows frequent operations.

- It has relatively low handling costs and risk of damage.

- It is more efficient and economical in short distance.

- It has transportation capacities in very different volumes

- The transportation vehicle is under the control of the sender/carrier to a large extent.

- It enables to increase and decrease the speed of the transportation.

- It provides easy adjustment with departure and arrival times.

Despite the fact that road freight transport is cheaper compared to air transport and has the advantage of delivering the goods in a short time compared to sea transport, it has serious disadvantages especially in terms of cost and safety in some countries. Taking a close look at these disadvantages, the following factors are observed. 
- The most important disadvantage of road freight transport is that it has higher transportation costs compared to other modes of transports.

- Fewer infrastructure investments compared to other modes

- Low amount of cargo transported at once

- Weight limitations

- Bad weather conditions

- Sensitive to the load balance of both ways

- Inadequate equipment at high volume deliveries

- Higher risk of an accident

- Environmental pollution, traffic density and occupying more inland, and infrastructure requirements

- Price uncertainty in market fluctuations

In addition to the disadvantages mentioned above, some significant risks emerging from the nature of international trade and the development of world trade await road freight transport. The fact that the world's major exporting/importing countries are in distant parts of the world makes sea transport advantageous. Today $95 \%$ of the world's trade is carried out by sea. However, due to the rapid developments in technology in the last 20 years, it is expected that road freight transport will make a competitive move parallel to the development in the world. In spite of these moves, there are some developments in the world trade processes that will put international road freight transport in a difficult position. It is important to take measures to ensure that our country's foreign trade is affected in the least way from these negative developments. For this purpose, the determination of the problems and risk factors encountered in international road freight transport is considered important for the success of the measures to be taken.

\section{Threats for Road Freight Transport}

Although road freight transport is not the most advantageous mode of transport in international trade, it has a significant place in Turkey's foreign trade. Turkey is one of the countries that have the largest transport fleet in Europe for the road freight transport of goods. Due to its location, it 
is possible to reach the EU territory where the most important foreign trade partners are located by an average of 40 hours of road transport. On the other hand, Russia and the emerging markets of Europe that constitute the formerly independent states are close to us. The Middle East and Gulf countries which have taken a significant share in the field of international trade for the last 15 years are also within our reach by about the same hours of transport. For these reasons, the road freight transport of goods has been important for Turkey's foreign trade, and it appears to be that way for a while. In addition to all these developments, according to the information compiled from the National Energy Efficiency Action Plan (2016), it is planned to develop combined transportation applications in freight transport in order to ensure a balanced distribution modes of tween transport. On the other hand, the external costs of transportation are closely monitored by the European Union (Janic, 2007, 37). Moreover, it is aimed to increase the share of rail transport over 15 percent and the passenger transportation over 10 percent in order to increase the share of rail and sea transports and to move to corridor-based approach in transportation planning (www. Lojipark.com). Thus, the share of the road freight transport of goods is planned to be reduced from $90 \%$ to $60 \%$ by the end of 2023 . This way, the share of other modes will increase. The aim is to reduce the fossil fuel consumption of motor vehicles and increase the share of the rail and sea transports by the city in the transportation of goods. According to data from 2015, about 25 percent of Turkey's final energy consumption has been realized in the transportation industry. The fact that $91.6 \%$ of the energy consumption in transportation is realized by road freight transport brings about the necessity to reduce the share of road freight transport in modern transportation systems, which is clearly stated in all platforms by all relevant institutions and international organizations. The common position is to increase the penalties for many issues such as "the delivery time commitment between pickup and delivery point, responsibility for lost, damaged, and stolen goods, moving on an available route in compulsory conditions, and carrying the loads back" in international road freight transport. As a matter of the provisions of the convention, Turkey is a party to the CMR Convention; therefore, application of the provisions of the agreement is essential.

In general evaluation, in addition to current problems such as severe financial conditions, penalties, and bureaucratic restrictions in business processes, the biggest threats to the industry are discussed in the following six factors. These are; 
1. Costs and pricing

2. Time factor and speed of delivery

3. Expansion of the distribution area

4. Sources of risk

5. Tonnage and quantity factor

6. Prohibitions and restrictions emerging from international agreements

In-depth interviews were conducted with five international transport companies that agreed to discuss how these six factors are perceived by the sector, and what kinds of negative developments are they experience in their businesses, and how to resolve them. As is known, the interview method is frequently used as a qualitative research method. In this study, it is concluded that the interview method is the most appropriate method to reach the results for the research. Steward and Cash (1985) describe this method as a mutual and interactive communication process based on asking and answering questions with a predetermined and serious purpose (as cited in Yıldırım and Şimşek, 2016, p.129). Interview method is an ideal method for uncovering the problems and opinions of the parties with a qualitative research especially on very different topics and topics with subtopics. When compared to other methods such as focus group interview, observation, or document review, the interview method discloses the problems of the sector and the perception of the sector representatives more clearly. For this reason, face-to-face interviews with sector representatives were planned and realized within the framework of a specific protocol. The researcher conducted the structured interview. Instead of a having a conversation, an interview form has been applied. The interview process allowed to maintain a flexible structure depending on the flow of the interview. This method also offers the possibility to elicit some answers that the sector representatives did not want to give away sooner with the help of further questioning. The distinctiveness of instant responses and in-depth discussion of some issues are also among the important advantages of the interview method. The main objective is to reveal the similarities and differences between the perceptions of the business managers interviewed, their perception of threats and the ways they perceive them, and their views on the solution. In doing so, it is holding a discussion on a predetermined subject. It is also presented to what extent the data from the interviews in the study agree with the literature. 


\section{Findings}

In this study, five volunteer businesses that are based in Ankara and have branches in Ankara were interviewed. The interviews were conducted with each business with a predetermined 6point interview protocol covering the points previously mentioned. As the names of the businesses are agreed to be kept confidential by both parties, the codes in the form of letters (A, B, C etc.) are used instead.

In the study, the answers are coded $(+,++,++)$ and tabulated by preparing separate tables for each factor addressed. In the process of the tabulation, the researcher tried to classify and shorten the interview data obtained in the form of texts with + statements.

The meaning of +'s (pluses) in all tables given above and in the following parts is as follows.

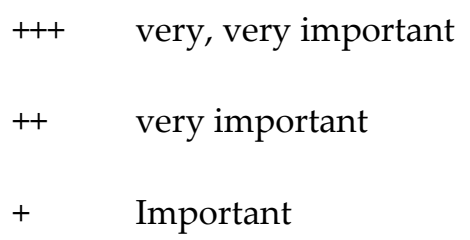

Table 1. Finding related to cost and pricing

\begin{tabular}{|l|l|l|l|l|l|}
\hline $\begin{array}{l}\text { Cost and } \\
\text { Pricing }\end{array}$ & Fuel & $\begin{array}{l}\text { Motorways } \\
\text { Tolls }\end{array}$ & $\begin{array}{l}\text { Unfair } \\
\text { Practices }\end{array}$ & Quato Costs & $\begin{array}{l}\text { No Return } \\
\text { Load }\end{array}$ \\
\hline Company A & +++ & +++ & ++ & ++ & ++ \\
\hline Company B & ++ & ++ & ++ & ++ & ++ \\
\hline Company C & ++ & ++ & + & ++ & + \\
\hline Company D & + & ++ & ++ & + & ++ \\
\hline Company E & +++ & +++ & ++ & + & ++ \\
\hline
\end{tabular}

For cost and pricing factors, different countries, especially the EU trade is not sufficient because of the commercial quota for Turkey. The existence of these quotas hinders potential trade. However, the companies we interviewed stated that they were not disturbed by the existence of these quotas. This point was found interesting 
When we think that the malitet items were taken in the following factors, it is seen that there are different factors in the study. It is aimed to ensure the flow of the logistics system from the production stage to the consumption phase.

The most important factors can be listed as follows:

Shipping type

Type of distribution operation

Installation planning

Route planning

Shipment includes not only movement from the supplier to the facility, but also from the warehouse to the customer. The cost of shipping is considered as the cost of distribution, regardless of which side (carrier or customer) is directly involved.

The cost-enhancing effect of the transport cannot be excluded. As the distance increases, the cost also increases, and as it opens out, appropriate logistics solutions must be available to maintain the competitiveness.

Changes in transport efficiency, improving the load factor (the amount of goods measured in tonnes, divided by vehicle capacity) by:

a. Optimizing the allocation of vehicles to shipments

b. Consolidating shipments originating from the same company

c. Consolidating shipments originating from several companies

d. Changing the number and location of depots, including consolidation and distribution centres e. Getting more return loads to reduce empty driving ( Jong and Oth., 2010, 5). 
Table 2. Finding related to time and speed

\begin{tabular}{|l|l|l|l|l|}
\hline $\begin{array}{l}\text { Time and } \\
\text { Speed } \\
\text { Factors }\end{array}$ & $\begin{array}{l}\text { Transit Times in } \\
\text { Customs }\end{array}$ & $\begin{array}{l}\text { Quaility of } \\
\text { Highways }\end{array}$ & Car Features & $\begin{array}{l}\text { Remote } \\
\text { Destination }\end{array}$ \\
\hline Company A & +++ & + & + & ++ \\
\hline Company B & ++ & ++ & + & +++ \\
\hline Company C & +++ & + & + & ++ \\
\hline Company D & ++ & ++ & + & ++ \\
\hline Company E & ++ & + & ++ & ++ \\
\hline
\end{tabular}

For time and speed factor, athough in the literature factors such as highway quality and vehicle characteristics are mentioned, enterprises state that the quality of motorways is not a significant factor. Vehicle features, however, did not present a disadvantage for Turkish businesses. Ouality of Highways includes roads, floors, tunnels, overpasses and overpasses and signs (Görçün, 2010,3).

Table 3. Finding related to width of services area

\begin{tabular}{|l|l|l|l|l|l|}
\hline $\begin{array}{l}\text { Width of } \\
\text { Area }\end{array}$ & $\begin{array}{l}\text { Exporters in } \\
\text { Far Regions }\end{array}$ & $\begin{array}{l}\text { Road } \\
\text { Transport } \\
\text { Agreements } \\
\text { in Remote } \\
\text { Areas }\end{array}$ & $\begin{array}{l}\text { Additional } \\
\text { Costs of } \\
\text { Remote } \\
\text { Regions }\end{array}$ & $\begin{array}{l}\text { The Choice } \\
\text { of Highways } \\
\text { in Remote } \\
\text { Areas to be }\end{array}$ & $\begin{array}{l}\text { No Transit } \\
\text { Route }\end{array}$ \\
\hline Company A & +++ & +++ & +++ & +++ & ++ \\
\hline Company B & ++ & +++ & ++ & +++ & ++ \\
\hline Company C & +++ & +++ & +++ & ++ & ++ \\
\hline Company D & ++ & +++ & +++ & +++ & +++ \\
\hline Company E & ++ & +++ & +++ & +++ & ++ \\
\hline
\end{tabular}


For the width of the service area, the limitation of transit transitions was not considered to be an important factor in contrast to the literature. Remote delivery points were not seen as a threat to road transport.

Effect of the same set of factors may vary significantly depending on the country or a particular area. For example, heavy snowfall may not cause long delays in areas where it is a usually occurring phenomenon as there are enough snow removal machines and most drivers are used to this type of weather conditions. On the other hand, even light snowfall may stop all traffic in regions that usually do not have snow at all. Also, the time of reaction of emergency services in case of some problems on roads may differ depending on the country (Sigakova, 2012,7).

Table 4. Finding related to sources of risks

\begin{tabular}{|l|l|l|l|l|}
\hline $\begin{array}{l}\text { Sources of } \\
\text { Risks }\end{array}$ & Thefts & $\begin{array}{l}\text { Surprise Driver } \\
\text { Visa Barriers }\end{array}$ & $\begin{array}{l}\text { Driver } \\
\text { Unavailability }\end{array}$ & Acciedent \\
\hline Company A & + & + & ++ & + \\
\hline Company B & + & ++ & ++ & + \\
\hline Company C & ++ & + & ++ & + \\
\hline Company D & + & ++ & +++ & + \\
\hline Company E & + & + & +++ & + \\
\hline
\end{tabular}

Risk is defined as uncertainly of situation or event which can negatively affect the performance of organization, or event that has a few probability to happen but can harm the organization both in short term and long term sustainability. The risks and theft risks foreseen by the literature within the risk sources factor are not considered as risk factors for Turkish enterprises.

The absence of drivers and the prolongation of total carriage times are other factors that have emerged in another study ( Hanssen ve others, 2012, 193). 
Table 5. Finding related to tonnage and Quantity

\begin{tabular}{|l|l|l|}
\hline $\begin{array}{l}\text { Tonnage and Quantity } \\
\text { Factors }\end{array}$ & Tonnage & Kinds of Products \\
\hline Company A & +++ & +++ \\
\hline Company B & ++ & +++ \\
\hline Company C & +++ & ++ \\
\hline Company D & ++ & +++ \\
\hline Company E & ++ & ++ \\
\hline
\end{tabular}

The nature and quantity of the product to be transported in foreign trade is an important factor for the selection of the transport mode. This sector can be closely monitored.

Table 6. Finding related to international Agreements Applications

\begin{tabular}{|l|l|l|l|l|}
\hline $\begin{array}{l}\text { International } \\
\text { Agreements } \\
\text { Applications }\end{array}$ & $\begin{array}{l}\text { Decrease in } \\
\text { Traceability }\end{array}$ & $\begin{array}{l}\text { Requesting } \\
\text { Multiple } \\
\text { Documents }\end{array}$ & $\begin{array}{l}\text { Data Input } \\
\text { Obligations }\end{array}$ & Trade Barriers \\
\hline Company A & ++ & +++ & +++ & ++ \\
\hline Company B & ++ & +++ & ++ & + \\
\hline Company C & ++ & ++ & +++ & ++ \\
\hline Company D & ++ & +++ & ++ & ++ \\
\hline Company E & ++ & +++ & +++ & ++ \\
\hline
\end{tabular}

The traceability of transport vehicles in international regions is not seen as a threat to enterprises. In the recent period, the existence of important software and technological developments have eliminated this problem.

Concern has been mounting over the environmental impact of freight transport operations. Although tightening vehicle emission standards have been reducing exhaust emissions of noxious gasses, such as nitrogen oxides, hydrocarbons, carbon monoxide and particulate matter, attention has shifted to the growth in carbon dioxide $\left(\mathrm{CO}_{2}\right)$ emissions from the freight sector. 
National governments and the EU have set targets for reducing all these emissions and devised policy measures to cut the external costs of freight transport (Piecky \& McKinnon, 2010,31).

\section{Conclusions}

In the scope of the study, interviews were held with the managers holding different positions in the five businesses that carry international goods. As a result of the findings obtained from the interviews, the researcher has reached the following results.

1. Among the existing problems, the businesses participating in the interview emphasize six factors as the most important problems that threaten the sector. These six factors that this study also focuses on appear to be the ones mentioned above.

Costs and pricing

Time factor and speed of delivery

Expansion of the distribution area

Sources of risk

Tonnage and quantity factor

Prohibitions and restrictions emerging from international agreements

However, as a result of the interviews, it is observed that there are sub-factors that bring about these 6 factors, and each sub-factor is evaluated separately.

2. The constant increase in fuel prices and tolls are notable, particularly among the cost factor. Another important point is the absence of a load on the way back. $72 \%$ of the Turkish transport vehicles exporting goods cannot find loads to be delivered to Turkey or a different location. The ratio of foreign carriers in Turkey's imports tend to rise. This ratio was 31\% in 2016 and went up to $35 \%$ in 2017. Especially Bulgarian, Iranian and Romanian carriers are noteworthy for this increase.

Another important disadvantage of the road transport is the expansion of the distribution area. Apart from our trade with the European Union, the Middle East or Russia and the Other Baltic States, the fact that Turkey does not have road transport agreements with more distant areas or multilateral agreements with these countries brings about crucial problems. The presence of transit restriction between Turkey and the EU and that these problems are not to be solved reduce 
the foreign trade approximately 3.5 billion euros single-handedly. 1.9 billion dollars of this amount can be added to Turkey's foreign trade as exports (www.ulasimonline.com). These distant geographies increase the risk factors as well as the costs. However, the most important problem is that the transporters do not prefer road freight transport after a certain distance.

4. The most important risk factors of road freight transport are discussed under two components. The most important risk factor is stated to be that it is becoming more and more challenging for employers to find good drivers. Drivers, on the other hand, express that due to low wages and the difficulty of working conditions, finding drivers will become even more important in the short time.

5. Another threat that was found out about is the shift of large quantities of deliveries in tonnage to the other modes of transport. Excluding air transport, especially sea transport and rail transport that has recently been promoted with international projects (e.g. one belt, one road) pose difficulties for road transport. The fact that some types of goods are not convenient to be carried out by the road transport makes this mode confined to certain sectors only.

6. Another important threat is the practices emerging from international agreements. Turkey is a party to international and multilateral agreements, and there is an increase in the number and types of documents in foreign trade for road freight transport. The increase in the number of documents in the last 10-year period is around 50\%.In 2006, the transportations needed 39 documents, and today the number increased to 58 (www.kargohaber.com). In addition, electronic data entries, which are also applicable in our country, are requested by different countries nowadays. Providing and monitoring the data correctly is extra workload on the carriers and a mistake, in this case, would cause delays and higher costs.

As a result, the share of road freight transport of goods within total transportation tends to decrease in parallel to the developments in the world. This decrease is slightly less than the average for Turkey. Therefore, road freight transport is more important for Turkey than in other countries. Furthermore, a large part of the problems mentioned above are the ones that can be eliminated by multilateral agreements. The resolution of these problems can be realized by taking macro measures on the basis of countries and not businesses and by making the new agreements. In this case, road freight transport of goods appears to have a higher risk perception than other modes of transport.

The development of road freight transport of goods will undoubtedly follow up with the increase in our export. The increase in innovative products with high value-added will also bring up other 
transportation modes over time. In addition to the exploratory results obtained from this qualitative research, the prospective studies can be carried out on the basis of the sector as well as the territories to transport.

\section{References}

Cora, A., (2016). Lojistik Notları, Hiperlink Yayınları No: 93,

Dölek, Ali. (2015). “Lojistik ve Nakliye İşlemleri”, İstanbul, Umut Kitap-Yayın Dağıtım.

Görçün, Ömer F. (2010). Karayolu Taşımacılı̆̆ı, Beta Yayınları.

Hannsen, T. E, Mathisen, T.A., and Jergensen, F. (2012). Generalized Transport Costs in Intermodal Freight Transport, Procedia - Social and Behaviour Sciences, 54, 189-200.

Janic, M. (2007). Modeling the Full Costs of an Intermodal and Road Freight Transport Network, Transportation Research, 12, 1: 33-44.

Jong De Gerard, Arno S., Huib van Essen,(2010). Price sensitivity of European Road Freight Transport - Towards a Better Understanding of Existing Results" A report for Transport $\mathcal{E}$ Environment.

Piecky, L.Maja \& Alan McKinnon, ( 2010). Forecasting The Carbon Footprint Of Road Freight Transport in 2020, International Journal of Production Ekonomics, 128 (1): 31-42.

Küçük, O. (2014). Lojistik Ilkeleri ve Yönetimi, Seçkin Yayınları.

Sigakova, K., (2019). Road Freight Transport Travel Time (Online) Prediction, https://www.divaportal.org/smash/get/diva2/fulltext01 (Erişim tarihi:10.04.2019)

Steward, C. J. ve Cash, W.B. (1985). Interwiewing : Principles and Practices, 4th. Ed., C. Brown Publishing.

Yıldırım, A. ve Şimşek H.(2016). Sosyal Bilimlerde Nitel Araştırma Yöntemleri, 10. Baskı, Seçkin Yayınları,

$\underline{\text { www.webnak.com .tr }}$

www.kargohaber.com.tr

www.ulasimhatti.com.tr 